\title{
Facial nerve palsy secondary to parotitis
}

\author{
Elaine Campbell $10,{ }^{1}$ Oliver McLaren ${ }^{2}$
}

'ENT, Royal Cornwall Hospitals NHS Trust, Truro, UK

${ }^{2}$ ENT, South Devon NHS Foundation Trust, Truro, UK

\section{Correspondence to} Dr Elaine Campbell; elaine.campbell13@nhs.net

Accepted 17 January 2021

\section{DESCRIPTION}

This 66-year-old woman, who was undergoing chemotherapy (weekly paclitaxel) for metastatic breast cancer, was admitted under the oncologists with dehydration secondary to vomiting and diarrhoea. While an inpatient, it was noted that she had developed a right-sided lower motor neuron facial nerve palsy. On further clinical examination, the right side of the neck was noted to be swollen and tender (see figures 1 and 2). Blood tests showed a marked inflammatory response with a white cell count of 18.0 and C reactive protein of 307 . An ultrasound showed a swollen right parotid gland, suggestive of parotitis which likely caused the facial nerve palsy. A CT scan was performed to ensure there was no abscess formation, as parotid abscess are an established cause of facial nerve palsy. ${ }^{1}$ The CT scan showed an inflamed parotid but no organised collection (see figure 3 ).

The working diagnosis was that the patient had developed chemotherapy related gastroenteritis, which caused dehydration, which likely contributed to her developing bacterial parotitis. While drug induced parotitis has been reported with some chemotherapy agents, it is a rare adverse drug reaction and has not been reported in patients taking paclitaxel. $^{2}$ Due to the raised inflammatory markers and clinical presentation, the authors were confident in the diagnosis of bacterial parotitis. As the facial palsy and parotitis developed simultaneously, it was felt that the facial palsy was likely due to compression of the facial nerve within the parotid.

The patient was managed non-surgically with intravenous antibiotics and oral steroids. The importance of good eye care was stressed, with regular eye-drops and taping of the eye at night to prevent corneal abrasions. The patient was advised that while the parotitis will improve in a matter of days, it is likely that the facial nerve palsy will take much longer to resolve. The patient was also

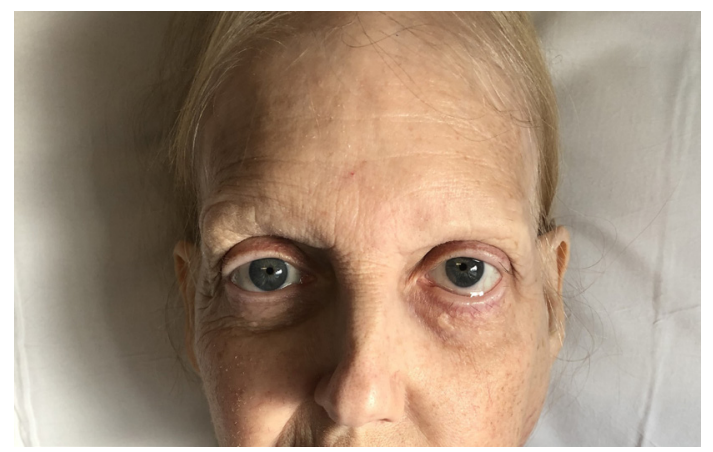

Figure 1 Left-sided facial nerve palsy with a swollen parotid ipsilaterally (with facial muscles at rest).

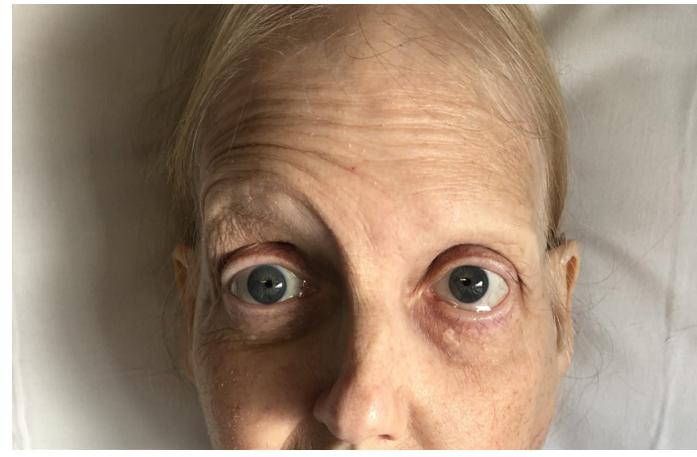

Figure 2 Left-sided facial nerve palsy with a swollen parotid ipsilaterally (when asked to raise eyebrows).

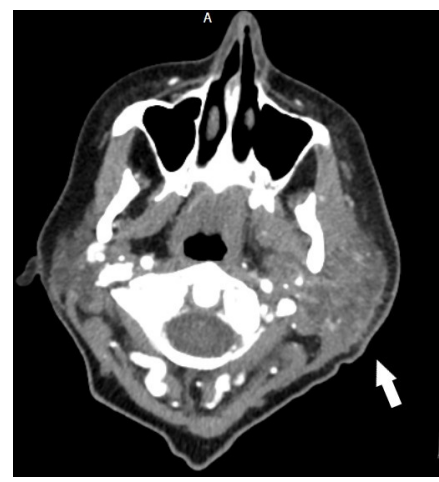

Figure 3 Axial CT head and neck showing an inflamed left parotid gland (arrow).

advised that there was a possibility that the facial weakness may never fully resolve.

\section{Learning points}

- A full head and neck exam, including neck examination, otoscopy, examination of the oral mucosa and testing off all cranial nerves, must be undertaken in all patients who present with a new lower motor neuron facial palsy.

- Bell's palsy is idiopathic facial nerve palsy-it must be a diagnosis of exclusion when no other cause can be found.

- Management should focus on treating any underlying cause and judicious use of steroids to reduce any perineural inflammation.

\section{Twitter Oliver McLaren @boomclaren}

Contributors EC and OM contributed equally and wholly to the planning, conduct and reporting of the work described in this article. EC and OM gave substantial contributions to the conception of the work and the interpretation of data. EC drafted the work and OM revised it critically for important intellectual content. EC and $\mathrm{OM}$ gave final approval of the version published. EC and OM agreed to be accountable for all aspects of the work in ensuring 


\section{Images in...}

that questions related to the accuracy or integrity of any part of the work are appropriately investigated and resolved.

Funding The authors have not declared a specific grant for this research from any funding agency in the public, commercial or not-for-profit sectors.

Competing interests None declared.

Patient consent for publication Obtained.

Provenance and peer review Not commissioned; externally peer reviewed.
ORCID iD

Elaine Campbell http://orcid.org/0000-0002-7355-3955

\section{REFERENCES}

1 Finsterer J. Management of peripheral facial nerve palsy. Eur Arch Otorhinolaryngol 2008:265:743-52.

2 Brooks KG, Thompson DF. A review and assessment of drug-induced parotitis. Ann Pharmacother 2012:46:1688-95.

Copyright 2021 BMJ Publishing Group. All rights reserved. For permission to reuse any of this content visit

https://www.bmj.com/company/products-services/rights-and-licensing/permissions/

BMJ Case Report Fellows may re-use this article for personal use and teaching without any further permission.

Become a Fellow of BMJ Case Reports today and you can:

- Submit as many cases as you like

- Enjoy fast sympathetic peer review and rapid publication of accepted articles

Access all the published articles

Re-use any of the published material for personal use and teaching without further permission

Customer Service

If you have any further queries about your subscription, please contact our customer services team on +44 (0) 2071111105 or via email at support@bmj.com.

Visit casereports.bmj.com for more articles like this and to become a Fellow 